\title{
Retraction Note: Dual versus mono antiplatelet therapy for acute non- cardio embolic ischemic stroke or transient ischemic attack, an efficacy and safety analysis - updated meta-analysis
}

\author{
Christessa Emille Que Albay*, Frederick Gavril D. Leyson and Federick C. Cheng
}

\author{
Retraction Note: BMC Neurol 20, 224 (2020) \\ https://doi.org/10.1186/s12883-020-01808-y
}

The Editor has retracted this article [1]. This was an updated meta-analysis that included two additional studies; however, one of the studies included in the metaanalysis (Johnson et al. 2016, [14] in the article) should not have been included because it reports data comparing Ticagrelor with Aspirin (i.e. mono versus mono antiplatelet therapy) rather than data comparing Ticagrelor plus Aspirin with Aspirin alone (i.e. dual versus mono anti-platelet therapy). As this study has a large sample size its inclusion will have undermined the results and conclusions presented. Christessa Emille Que. Albay and Federick C. Cheng agree with this retraction. Frederick Gavril D. Leyson has not responded to correspondence from the Editor about this retraction.

Published online: 17 December 2020

\section{Reference}

1. Albay CEQ, Leyson FGD, Cheng FC. Dual versus mono antiplatelet therapy

for acute non- cardio embolic ischemic stroke or transient ischemic attack, an efficacy and safety analysis - updated meta-analysis. BMC Neurol. 2020; 20:224. https://doi.org/10.1186/s12883-020-01808-y.

The original article can be found online at https://doi.org/10.1186/s12883 020-01808-y.

*Correspondence: camillequealbay@gmail.com

Cardinal Santos Medical Center, 10 Wilson St. Greenhills West, 1502 San Juan City, NCR, Philippines

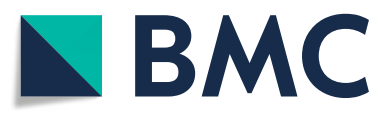

(c) The Author(s). 2020 Open Access This article is licensed under a Creative Commons Attribution 4.0 International License, which permits use, sharing, adaptation, distribution and reproduction in any medium or format, as long as you give appropriate credit to the original author(s) and the source, provide a link to the Creative Commons licence, and indicate if changes were made. The images or other third party material in this article are included in the article's Creative Commons licence, unless indicated otherwise in a credit line to the material. If material is not included in the article's Creative Commons licence and your intended use is not permitted by statutory regulation or exceeds the permitted use, you will need to obtain permission directly from the copyright holder. To view a copy of this licence, visit http://creativecommons.org/licenses/by/4.0/ The Creative Commons Public Domain Dedication waiver (http://creativecommons.org/publicdomain/zero/1.0/) applies to the data made available in this article, unless otherwise stated in a credit line to the data. 